\title{
PLACE OF WHEATEAR SPECIES WITHIN THE AVIFAUNA OF GHARDAÏA (ALGERIAN SAHARA)
}

\author{
Abdelwahab Chedad 1, 2,3*, Djamel Bendjoudi ${ }^{4}$, Omar Guezoul ${ }^{2,5}$ \\ ${ }^{1}$ University Kasdi Merbah, Department of Biological Sciences, Ouargla, Algeria \\ ${ }^{2}$ Laboratory of Saharan Bio-ressources: Preservation and Valorisation, Ouargla, Algeria \\ ${ }^{3}$ Directorate of Forest Conservation of Ghardaïa (General Directorate of Forestry) \\ ${ }^{4}$ University of Blida 1, Laboratory of Biotechnology, Environment and Health, Blida, Algeria \\ ${ }^{5}$ University Kasdi Merbah, Department of Agricultural Sciences, \\ Faculty of Nature Sciences and Life, Ouargla, Algeria
}

\begin{abstract}
The wheatears occupy a special place within the avifauna of the Ghardaïa region (Northern Algerian Sahara), with eight species. The range mapping and phenological status were studied in the Ghardaïa region between 2017 and 2021 on the basis of monthly sampling using Progressive Frequency Sampling (Echantillonnage Fréquentiel Progressif "EFP") method. Eight species of the genus Oenanthe were reported, two of which have a resident breeder phenological status (White-crowned Wheatear Oenanthe leucopyga, Desert Wheatear Oenanthe deserti), four species (Isabelline Wheatear Oenanthe isabellina, Northern Wheatear Oenanthe oenanthe, Black-eared Wheatear Oenanthe hispanica, and Mourning Wheatear Oenanthe lugens), having a passage visitor status. Buff-rumped Wheatear Oenanthe moesta with probably winter visitor status. Finally, a dubious sighting of Seebohm's wheatear Oenanthe seebohmi. Globally, all reported species are categorized as a species of the least concern $(L C)$ on the IUCN Red List of threatened species.
\end{abstract}

Keywords: Algerian Sahara, cartography, EFP, Ghardaïa, phenological status, wheatears.

\section{INTRODUCTION}

Algeria belongs to the Western Palearctic, borders the Mediterranean Sea to the north, and Countries of the Sahel to the south. It has a great diversity of climates (subtropical, Mediterranean, semi-arid, and arid) (Stevenson et al., 1988; Samraoui \& De Belair, 1998). Its geographical location, with all its features, makes it play a very important role in biological diversity (faunistic and floristic), ecological, landscape, and cultural (Chedad et al., 2020a).

The desert of Algerian Sahara covers an area of nearly 2 million $\mathrm{Km}^{2}$, about 85\% (Mediouni, 1997). Its climate characterized in particular by low and irregular rainfall, as well as by the pronounced thermal amplitudes between day and night and between months (Doumandji \& Doumandji-Mitiche, 1994).

The wheatears occupy a special place among the avifauna of North Africa (Arnault, 1931). They constitute a wide range of genus among the Muscicapidae with nine species reported in Algeria, of which eight species cited by Isenmann \& Moali, (2000) and Shirihai \& Svensson (2018) (Isabelline Wheatear Oenanthe isabellina, Northern Wheatear Oenanthe Oenanthe, Black-eared Wheatear Oenanthe hispanica, Desert Wheatear Oenanthe deserti, Buff-rumped Wheatear Oenanthe moesta, Mourning Wheatear Oenanthe lugens, and White-crowned Wheatear Oenanthe

\section{http://www.natsci.upit.ro}

*Corresponding author, E-mail address: agrochedad@yahoo.fr 
leucopyga) and one species cited by Shirihai \& Svensson (2018), this is Seebohm's Wheatear Oenanthe seebohmi. The purpose of this study is to update the species of wheatears (sedentary and migratory), show their place within the avifauna of the northern Algerian Sahara in Ghardaïa, to map their geographical range and to identify their phenological status.

\section{MATERIALS AND METHODS}

This study was carried out in Ghardaïa, located in the central part of the northern Algerian Sahara (Heim De Balsac \& Mayaud, 1962), which is part of the Saharan bioclimatic. It is characterized by very low and irregular annual precipitation.

For monitoring and mapping the range of certain wheatears species and define the phenological status of each of them, we adopted to the Progressive Frequency Sampling (Echantillonnage Fréquentiel Progressif "EFP") method, which is a point-sampling technique (Blondel, 1975), have already been using in Algeria by several authors such as Moali (1999), Bendjoudi et al. (2013), Farhi (2014), Souttou et al. (2018), Chedad et al. (2020a and b) and Chedad et al. (2021).

In the present study, the surveys were carried out during the period from 2017 to 2020, where the observer remains motionless is mentioned all the species of the genus wheatears, visually or acoustically contacted in an imaginary circle of $100 \mathrm{~m}$ in diameter. The recorded species will be noted in the absence/presence, for each station visited throughout the territory of the Ghardaïa region (Ochando, 1988; Fonderflick, 2006).

The protection status of bird species was assessed internationally according to the IUCN Red List (IUCN 2020). Finally, we have mapped and updated maps of geographical distribution. Using species occurrence data from the current study, complemented with additional occurrence data derived from BirdLife International and GBIF between the year 2001 - 2021 (www.gbif.org). ArcGIS (version 10.2.2 for Desktop: Esri®) was used to produce species distribution maps.

\section{RESULTS AND DISCUSSIONS}

In the Ghardaiia region, eight species of wheatears have reported of the 09 species recorded nationally, of which two species have a resident breeder phenological status (White-crowned Wheatear, Desert Wheatear), four species having a passage visitor status (Isabelline Wheatear, Northern Wheatear, Black-eared Wheatear, and Mourning Wheatear), Buff-rumped Wheatear is in principle winter visitor status. Finally, a dubious sighting of Seebohm's wheatear, where probably this species crosses the Ghardaïa region (Table 1).

\section{A- White-crowned Wheatear}

This species characterize the Saharan regions, notably Ghardaïa, where we observe it on the whole territory, in the Chebka of M'zab (Oued Ntissa, Oued M'zab, El Atteuf, Noumérat, Oued Nechou, Béni-Isguen, Mélika, Bounoura...); in the region of Guerrara and Berriane in the North to El Ménéa and Hassi El Gara in the South, as already cited by Chedad et al., (2018). This Wheatear can live far from man and frequents rocky places, Dayas, wetlands, or next to the man in Oases, palm groves, and urban agglomerations (Figure 1A and 1B). It should be remembered that the first case of leucism in the White-crowned Wheatear was reported in Ghardaïa on December 8, 2018 (Chedad et al., 2019).

In Algeria, there is the subspecies Oenanthe leucopyga leucopyga (Shirihai \& Svensson, 2018); its phenological status is a resident breeder. The range of this species extends from Algerian northern Sahara to the extreme limit of southern Algeria [Shirihai \& Svensson (2018), Isenmann \& Moali (2000), gbif.org (2021a)], with an expansion towards the Tellian Atlas and a little further north 


\section{Current Trends in Natural Sciences}

Vol. 10, Issue 19, pp. 25-35, 2021

https://doi.org/10.47068/ctns.2021.v10i19.003

Current Trends in Natural Sciences (on-line)

ISSN: $2284-953 \mathrm{X}$

Current Trends in Natural Sciences (CD-Rom)

ISSN: 2284-9521

ISSN-L: 2284-9521

ISSN-L: 2284-9521

(BirdLife International, 2016a). In Northern Sahara, this species is reported in Biskra, Ghardaïa, and Ouargla [(Guezoul et al. (2012 and 2017); Farhi and Belhamra (2012); Ababsa et al. (2013)]. Our observations confirm the nesting and sedentarization of the subspecies $O$. l. leucopyga in the different ecosystems of the territory of Ghardaïa.

Table 1 Checklist of wheatear species inventoried in the Ghardaïa region

\begin{tabular}{|c|c|c|c|c|c|c|c|c|c|c|c|c|c|c|c|c|c|c|}
\hline $\mathbf{N}^{\circ}$ & \multicolumn{12}{|c|}{ Species \& Monthly chart } & \multicolumn{5}{|c|}{ Annual Chart } & Phenological status \\
\hline \multicolumn{19}{|c|}{ White-crowned Wheatear Oenanthe leucopyga } \\
\hline 01 & $\overline{\mathrm{J}}$ & $\overline{\mathrm{F}}$ & M & $\overline{\mathrm{A}}$ & $\overline{\mathrm{M}}$ & $\overline{\mathrm{J}}$ & $\overline{\mathrm{J}}$ & $\overline{\mathrm{A}}$ & $\bar{s}$ & $\overline{0}$ & $\overline{\mathrm{N}}$ & $\overline{\mathrm{D}}$ & 2017 & 2018 & 2019 & 2020 & 2021 & $\mathrm{RB}$ \\
\hline \multicolumn{19}{|c|}{ Buff-rumped Wheatear Oenanthe moesta } \\
\hline 02 & $\mathbf{J}$ & $\mathbf{F}$ & $\mathbf{M}$ & A & M & $\mathbf{J}$ & $\mathbf{J}$ & A & $\mathbf{s}$ & o & $\mathbf{N}$ & D & 2017 & 2018 & 2019 & 2020 & 2021 & WV \\
\hline \multicolumn{19}{|c|}{ Desert Wheatear Oenanthe deserti } \\
\hline $\mathbf{0 3}$ & $\mathbf{J}$ & $\mathbf{F}$ & M & $\mathbf{A}$ & M & $\mathbf{J}$ & $\mathbf{J}$ & $\mathbf{A}$ & $\mathrm{s}$ & o & $\mathbf{N}$ & D & 2017 & 2018 & 2019 & 2020 & 2021 & $\mathrm{RB}$ \\
\hline \multicolumn{19}{|c|}{ Mourning Wheatear Oenanthe lugens } \\
\hline 04 & $\overline{\mathrm{J}}$ & $\mathbf{F}$ & $\mathbf{M}$ & A & M & $\bar{J}$ & $\mathbf{J}$ & A & $\mathrm{s}$ & o & $\mathbf{N}$ & $\mathbf{D}$ & 2017 & 2018 & 2019 & 2020 & 2021 & PV \\
\hline \multicolumn{19}{|c|}{ Isabelline Wheatear Oenanthe isabellina } \\
\hline 05 & $\bar{J}$ & $\bar{F}$ & $\mathrm{M}$ & A & $\mathbf{M}$ & $\bar{J}$ & $\mathbf{J}$ & $\mathbf{A}$ & $\overline{\mathrm{s}}$ & 0 & $\mathrm{~N}$ & D & 2017 & 2018 & 2019 & 2020 & 2021 & $\mathrm{PV}$ \\
\hline \multicolumn{19}{|c|}{ Northern Wheatear Oenanthe oenanthe } \\
\hline 06 & $\mathbf{J}$ & $\mathbf{F}$ & M & A & $\bar{M}$ & $\mathbf{J}$ & $\mathbf{J}$ & A & S & o & $\mathbf{N}$ & D & 2017 & 2018 & 2019 & 2020 & 2021 & PV \\
\hline \multicolumn{19}{|c|}{ Black-eared Wheatear Oenanthe hispanica } \\
\hline 07 & $\mathbf{J}$ & F & M & A & M & $\mathbf{J}$ & $\mathbf{J}$ & A & $\mathrm{S}$ & o & $\mathbf{N}$ & D & 2017 & 2018 & 2019 & 2020 & 2021 & PV \\
\hline \multicolumn{19}{|c|}{ Seebohm's Wheatear Oenanthe seebohmi } \\
\hline 08 & $\bar{J}$ & $\bar{F}$ & $\mathrm{M}$ & $\bar{A}$ & $\bar{M}$ & $\bar{J}$ & $\bar{J}$ & $\bar{A}$ & $\bar{s}$ & $\overline{0}$ & $\mathrm{~N}$ & D & 2017 & 2018 & 2019 & 2020 & 2021 & PV \\
\hline
\end{tabular}

Phenological status [WV: Winter Visitor, PV: Passage Visitor, RB: Resident Breeder].

\section{B- Buff-rumped Wheatear}

This species reported in winter in 2017 and 2020 in wetlands in Metlili and Berriane, subsequently another observation in Berriane in May 2020. The Buff-rumped Wheatear has a winter visitor status and is probably a passage visitor in some cases (Figure 2A and 2B). In Algeria, the phenological status of this species is resident breeder, and appears in the lower areas Aures between Batna and El Kantra, occupies the chott El Hodna and overflows largely to the north of the Highlands. It is abundant in the plateaus (Barika, Ain Oussera, Mechria), in the steppes between Djelfa and Laghouat. The Buff-rumped Wheatear is also reported in Ain Sefra, Touggourt, Moghrar, Beni Ounif, Ghardaïa, and El Golea (Isenmann \& Moali, 2000). According to recent publications by BirdLife International (2018), Shirihai \& Svensson (2018), and gbif.org (2021b), the Buff-rumped Wheatear is distributed mainly between the northern part of the Tellian Atlas and the Northern Sahara, where Farhi \& Belhamra (2012) report it in Biskra. Our observations in Ghardaïa granted as a recent observation. 
Current Trends in Natural Sciences

Vol. 10, Issue 19, pp. 25-35, 2021

https://doi.org/10.47068/ctns.2021.v10i19.003

Current Trends in Natural Sciences (on-line)

ISSN: 2284-953X

ISSN-L: 2284-9521
Current Trends in Natural Sciences (CD-Rom)
ISSN: 2284-9521

ISSN-L: 2284-9521

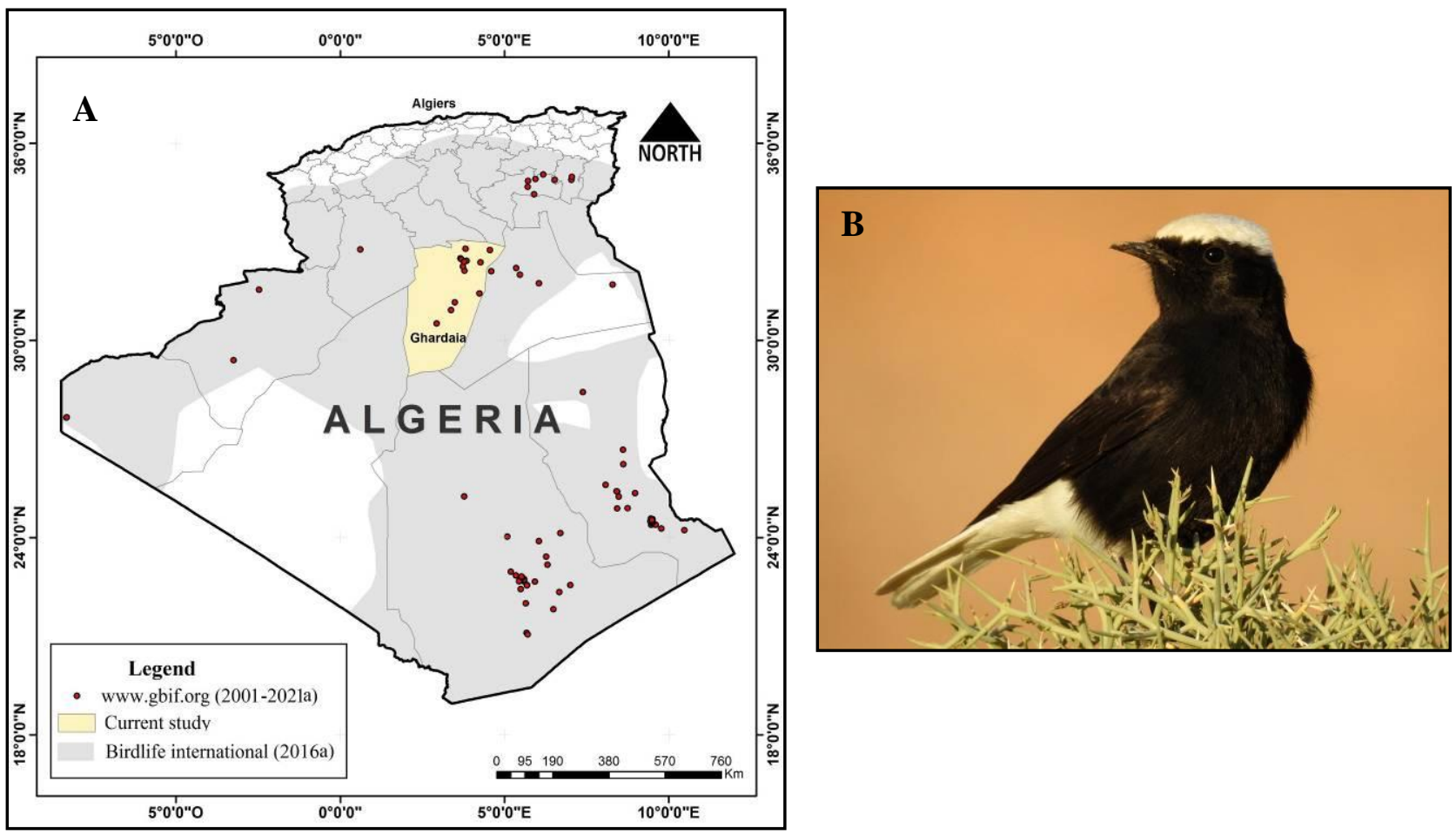

Figure 1A. Maps showing previous and updated distributions of the White-crowned Wheatear (Oenanthe leucopyga) in Algeria

Figure 1B. White-crowned Wheatear (Oenanthe leucopyga), Oued El Bir, Ghardaïa, Algeria 22/12/2018 $\odot$ A. Chedad

\section{C- Desert Wheatear}

It is a species that characterize semi-desert and desert regions, especially in Ghardaïa, where this species often observes throughout the territory of this region, in the Dayas, the Chebka, wetlands..., but it does not get too close to urban agglomeration. In Ghardaïa, the Desert Wheatear is a resident breeder (Figures 3A and 3B). In Algeria, there is the subspecies Oenanthe deserti homochroa, which is a resident breeder, and inhabits the steppe regions and extended towards the extreme south [Isenmann \& Moali, (2000); Shirihai \& Svensson, (2018); BirdLife International, (2016b) and gbif.org (2021c)]. In Northern Sahara, this species reported in Biskra, Ghardaïa, and Ouargla [Guezoul et al. (2012 and 2017); Farhi \& Belhamra (2012)]. 


\section{Current Trends in Natural Sciences}

Vol. 10, Issue 19, pp. 25-35, 2021

Current Trends in Natural Sciences (on-line) https://doi.org/10.47068/ctns.2021.v10i19.003

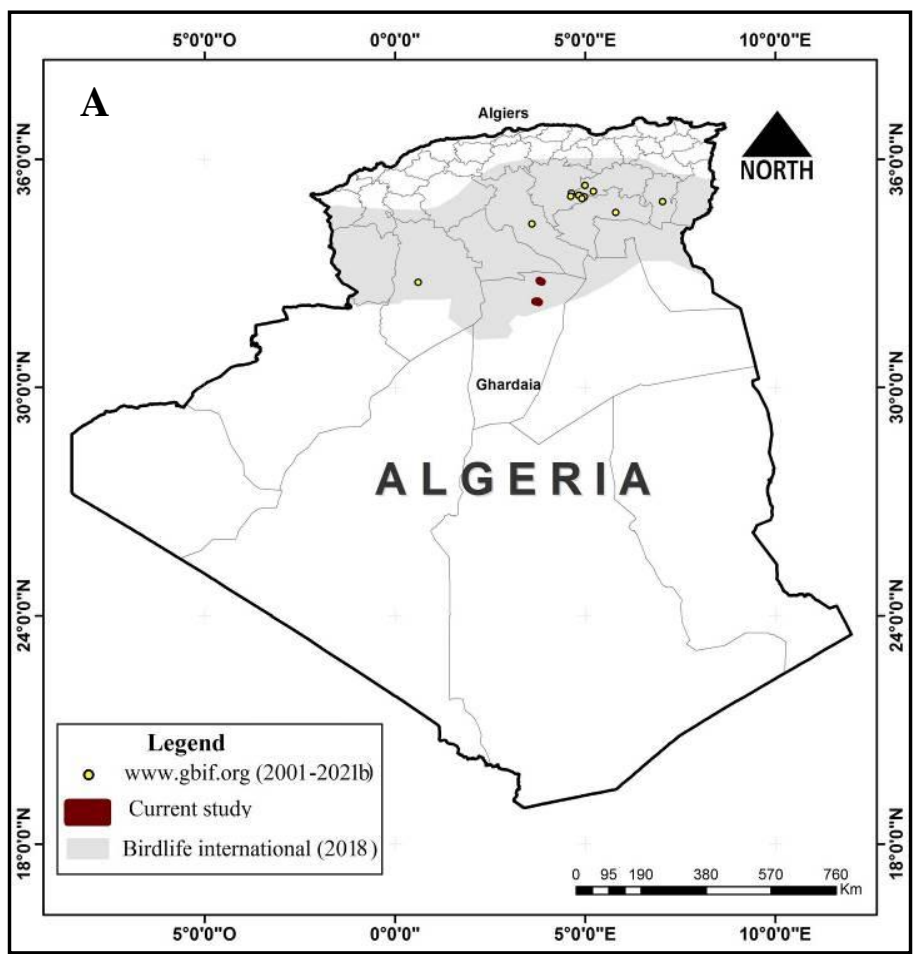

\section{B}

Figure 2A. Maps showing previous and updated distributions of the Red-rumped Wheatear (Oenanthe moesta) in Algeria

Figure 2B. Red-rumped Wheatear (Oenanthe moesta), Oeud Metlili, Ghardaïa, Algeria 27/12/2017 @ A. Chedad
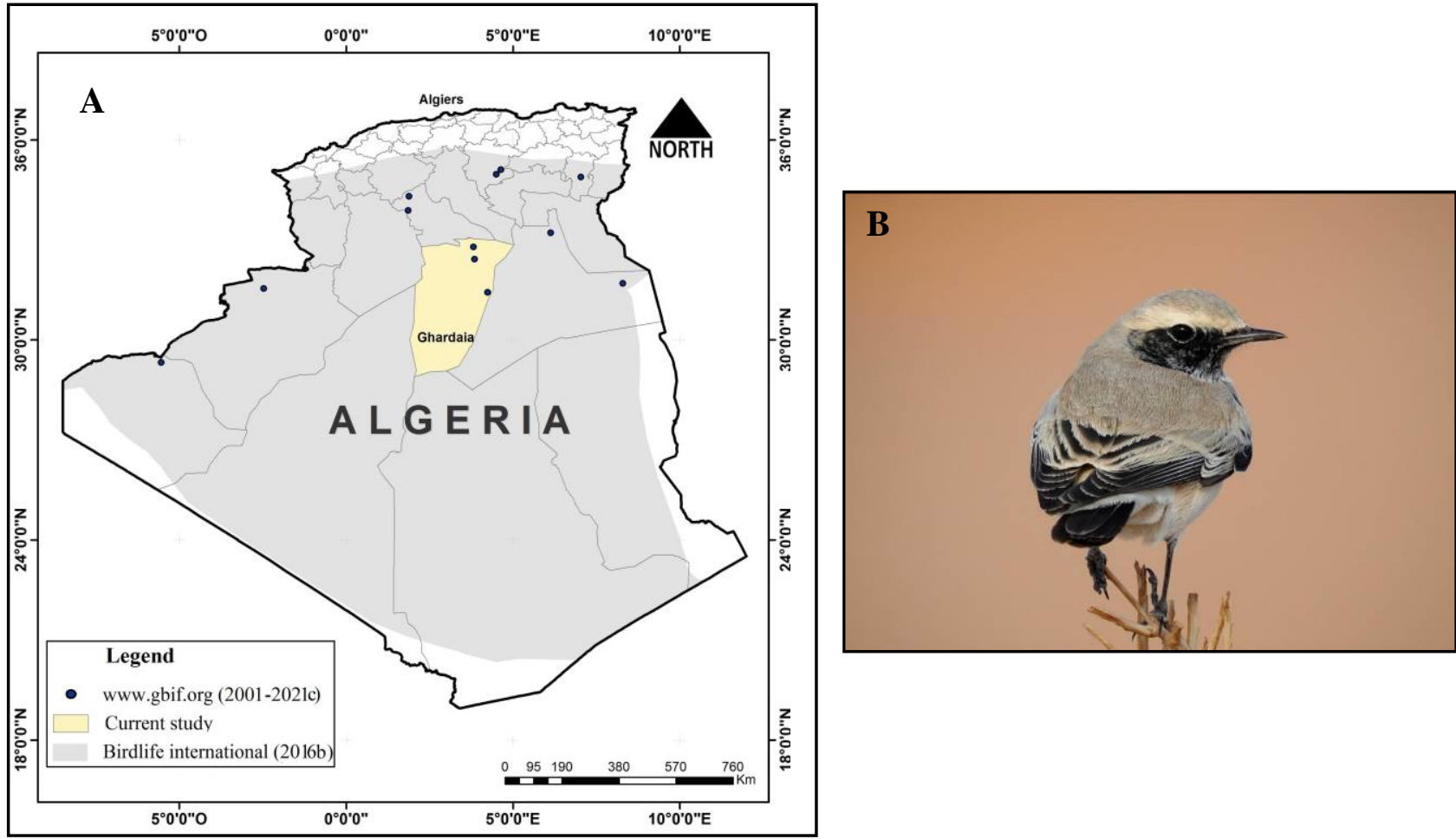

Figure 3A. Maps showing previous and updated distributions of the Desert Wheatear (Oenanthe deserti) in Algeria. Figure 3B. Desert Wheatear (Oenanthe deserti), Oued El Bir, Ghardaïa, Algeria 02/11/2018 $\odot$ A. Chedad 


\section{Current Trends in Natural Sciences}

Vol. 10, Issue 19, pp. 25-35, 2021

https://doi.org/10.47068/ctns.2021.v10i19.003

Current Trends in Natural Sciences (on-line)

ISSN: 2284-953X

Current Trends in Natural Sciences (CD-Rom)

ISSN: 2284-9521

ISSN-L: 2284-9521

ISSN-L: 2284-9521

\section{D- Mourning Wheatear}

In Ghardaïa, this species encountered only once, in January 2017 in Oued El Bir (Berriane). The Mourning Wheatear is a non - regular visitor and probably non-regular wintering (Figures 4A and 4B). In Algeria, there is the subspecies Oenanthe lugens halophila, a resident breeder species that prefer rocky biotopes, as well as clay slopes and banks of wadis, the northern limit of its distribution follows the Saharan Atlas (El Kantra, Messad, and Figuig, with observations at T'kout in the Aures, Chaiba in the Zab Mountains). To the south, the Mourning Wheatear reaches Ouargla, Zirara in M'zab and El Goléa, Hoggar, Tassili, and Beni Abbès [Isenmann \& Moali (2000) and BirdLife International, (2019a)]. According to Shirihai \& Svensson (2018), the range of the Mourning Wheatear confines mainly to the Saharan Atlas, with an isolated observation reported in Boussaâda by gbif.org (2021d). Our observations in Ghardaïa considered as recent records for the Algerian Sahara.
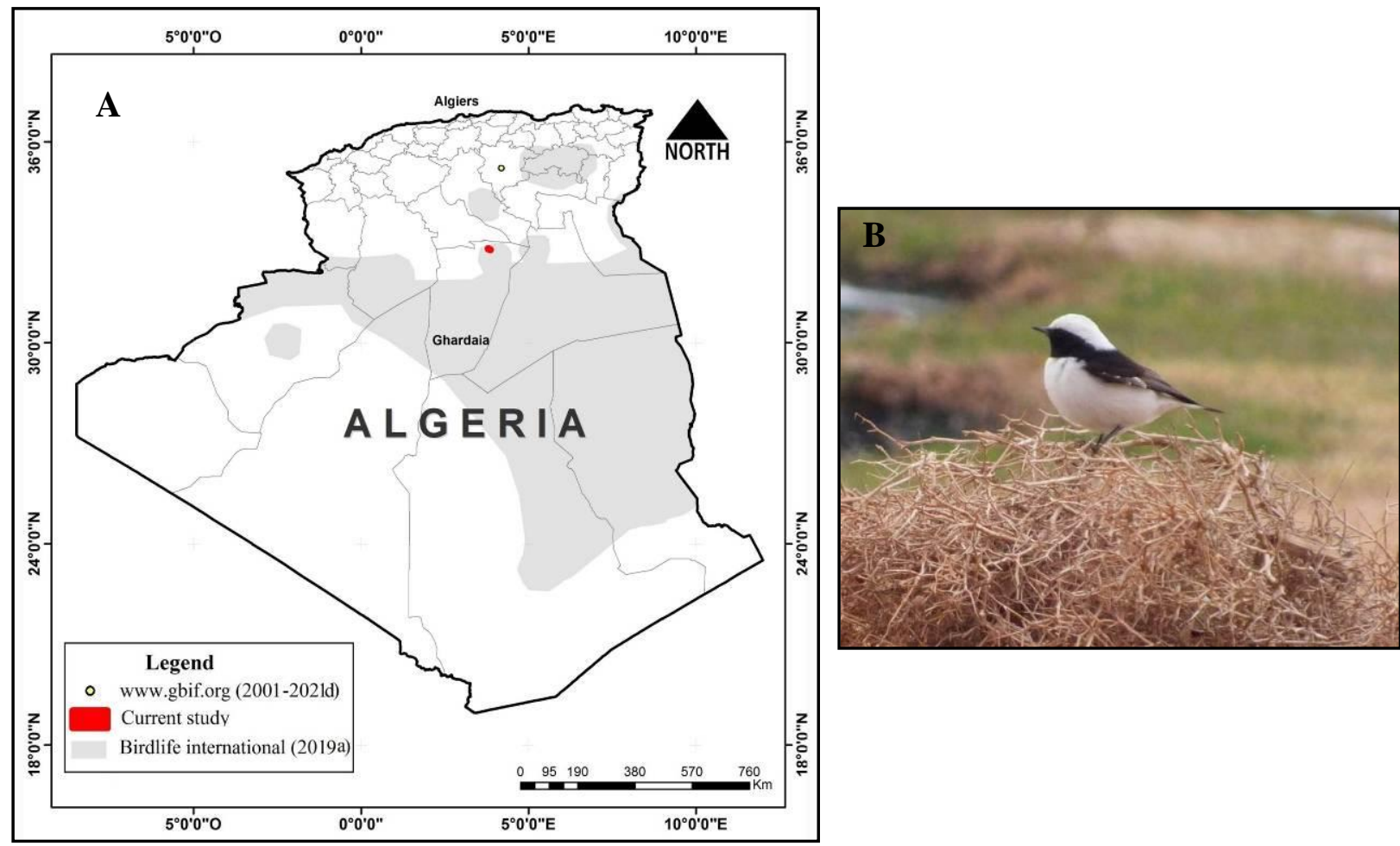

Figure 4A. Maps showing previous and updated distributions of the Mourning Wheatear (Oenanthe lugens halophila) in Algeria

Figure 4B. Mourning Wheatear (Oenanthe lugens), Oued El Bir à Berriane, Ghardaïa, Algeria 16/01/2017 @ A. Chedad

\section{E- Isabelline Wheatear}

It is a species that carries a passage visitor status, where we met her twice, during the prenuptial passage, during two successive years (2019 and 2020) in February and March in Kef Doukhane and Noumérate (Figure 5A and 5B). In Algeria, the phenological status of the Isabelline Wheatear is a passage visitor, it observed in several regions: Tamanrasset, In Guezzam, Djanet, Tassili, Hoggar Tiout, Béni Abbès, and Timimoun (Isenmann \& Moali, 2000), with an old mention on the presence of the species in Ghardaïa cited by Heim De Balsac \& Mayaud (1962) In Isenmann \& Moali (2000). 
Recent observations between 2001 and 2021 were reported at Naama, Hoggar, Ouargla, and Khenchla (gbif.org, 2021e). Our present observations in Ghardaïa considered recent and constitute new data on the migratory passage of the Isabelline Wheatear in Algeria.

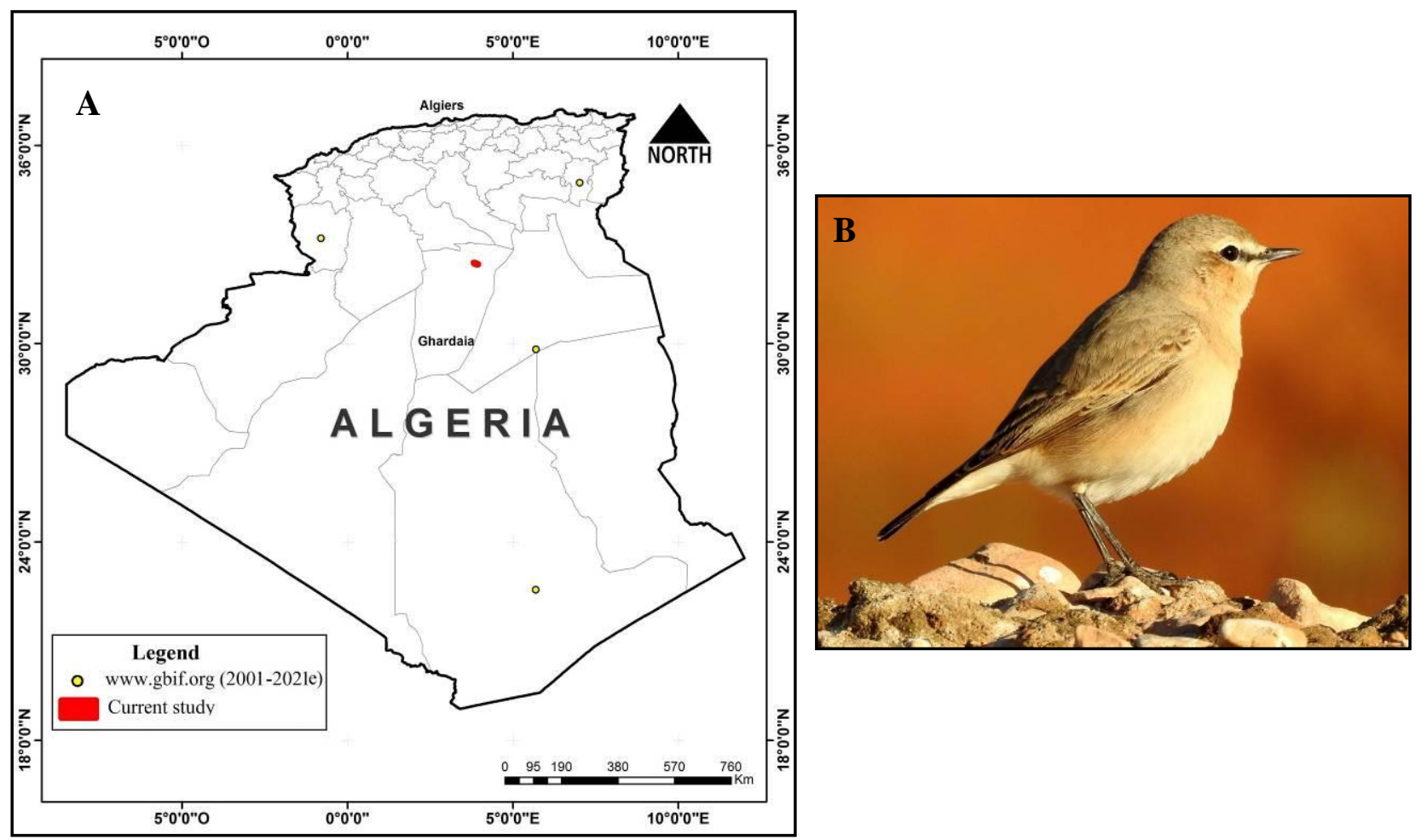

Figure 5A. Maps showing previous and updated distributions of the Isabelline Wheatear (Oenanthe isabellina) in Algeria

Figure 5B. Isabelline Wheatear (Oenanthe isabellina), Kef Doukhane, Ghardä̈a, Algeria 02/03/2019 @ A. Chedad

\section{F- Northern Wheatear}

This species is very abundant in the different ecosystems of the Ghardaïa region; it is recorded every year during the two migratory passages, prenuptial between March-May and postnuptial between September-November (Figure $6 \mathrm{~A}$ and 6B). In Algeria, the Northern Wheatear is a resident breeder and a passage visitor. These species cross the Algerian Sahara to go and nesting there in the north (Isenmann \& Moali, 2000). In Northern Sahara, this species reported in Biskra, Ghardaïa, and Ouargla [Guezoul et al. (2012 and 2017); Farhi \& Belhamra (2012)].

\section{G- Black-eared Wheatear}

This species recorded each year with numbers such as that of the Northern Wheatear, it observed during the two migration passages, prenuptial between March-May and postnuptial between September-October (Figure 7A and 7B). In Algeria, the Northern Wheatear is a resident breeder and a passage visitor. The Black-eared Wheatear crosses the Algerian Sahara to go and Nesting there to the north between the sea and the Saharan border (Biskra, Laghouat and Ain Sefra) [Isenmann \& Moali (2000), BirdLife International, (2019b) and Shirihai \& Svensson, (2018)]. Our observation shows the dates of annual migratory passage and reflects the place of the Ghardaiia region in the migratory flows of this species. 


\section{Current Trends in Natural Sciences}

Vol. 10, Issue 19, pp. 25-35, 2021

Current Trends in Natural Sciences (on-line) https://doi.org/10.47068/ctns.2021.v10i19.003
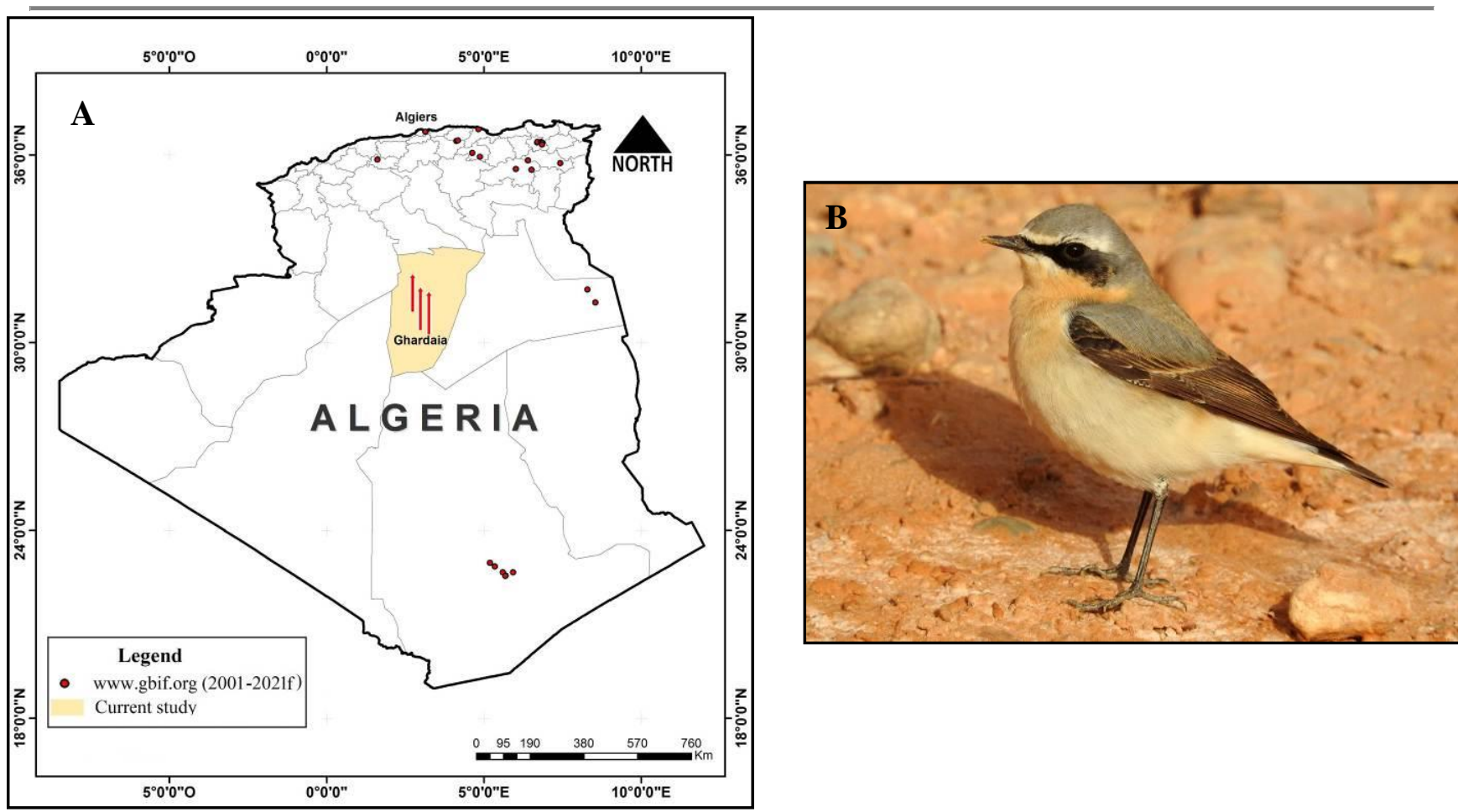

Figure 6A. Maps showing previous and updated distributions of the Northern Wheatear (Oenanthe Oenanthe) in Algeria

Figure 6B. Northern Wheatear (Oenanthe Oenanthe), Kef Doukhane, Ghardä̈a, Algeria 26/03/2018 $\odot$ A. Chedad
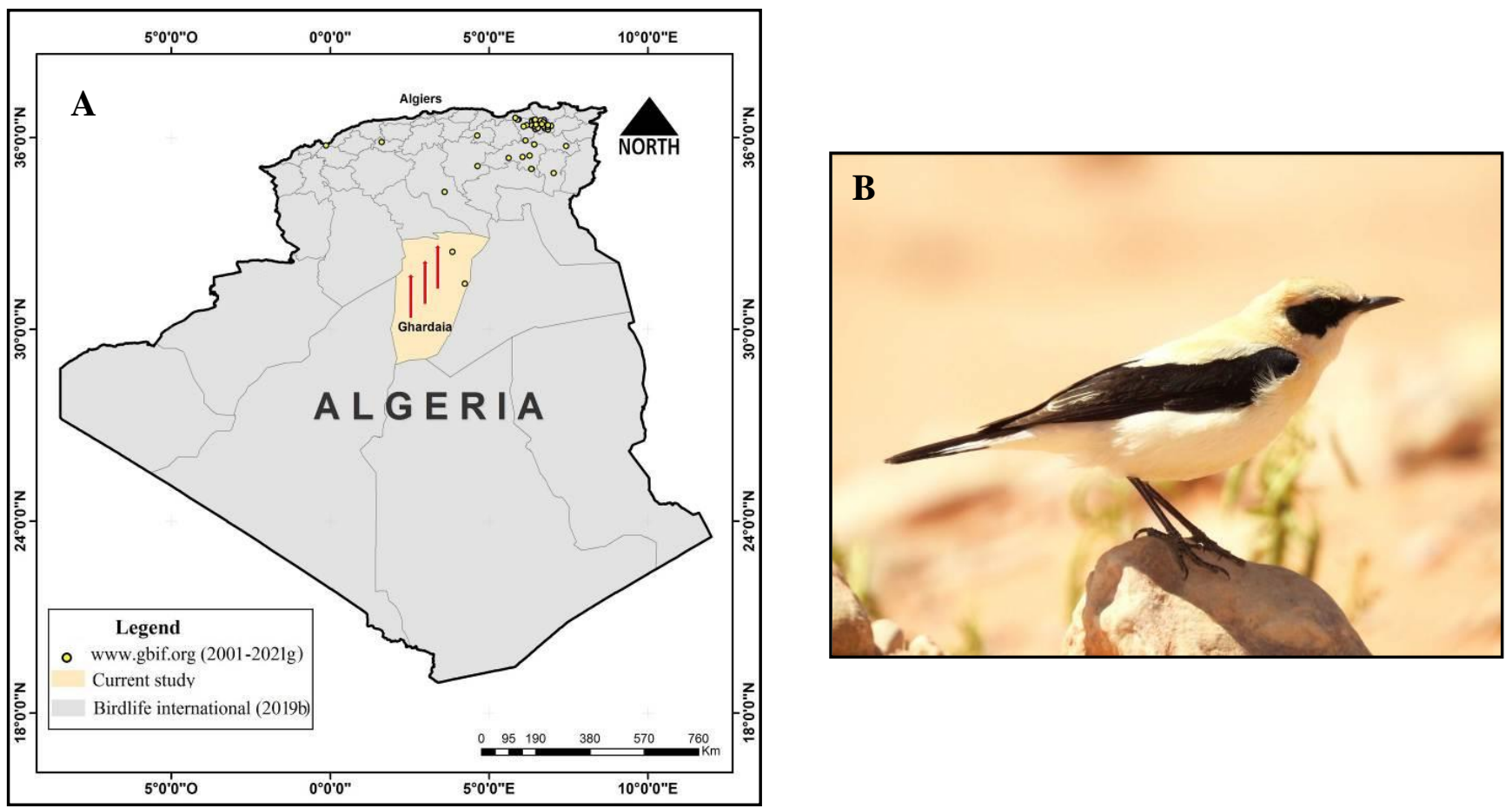

Figure 7A. Maps showing previous and updated distributions of the Western Black-eared Wheatear (Oenanthe hispanica) in Algeria

Figure 7B. Black-eared Wheatear (Oenanthe hispanica), Kef Doukhane, Ghardaïa, Algeria 27/03/2018 @ A. Chedad G- Black-throated Wheatear 
This species observed only once in May 2020, with a dubious observation, given the reason for the great similarity with the female of the Northern Wheatear. In Algeria, its phenological status is migrant breeder and passage visitor. The Black-throated Wheatear crosses the southwest of Algeria to go and nestled in the northeast [BirdLife International, (2016c) and Shirihai \& Svensson, (2018)]. Our observation remains doubtful, although we will be confirmed in the future by other observations.

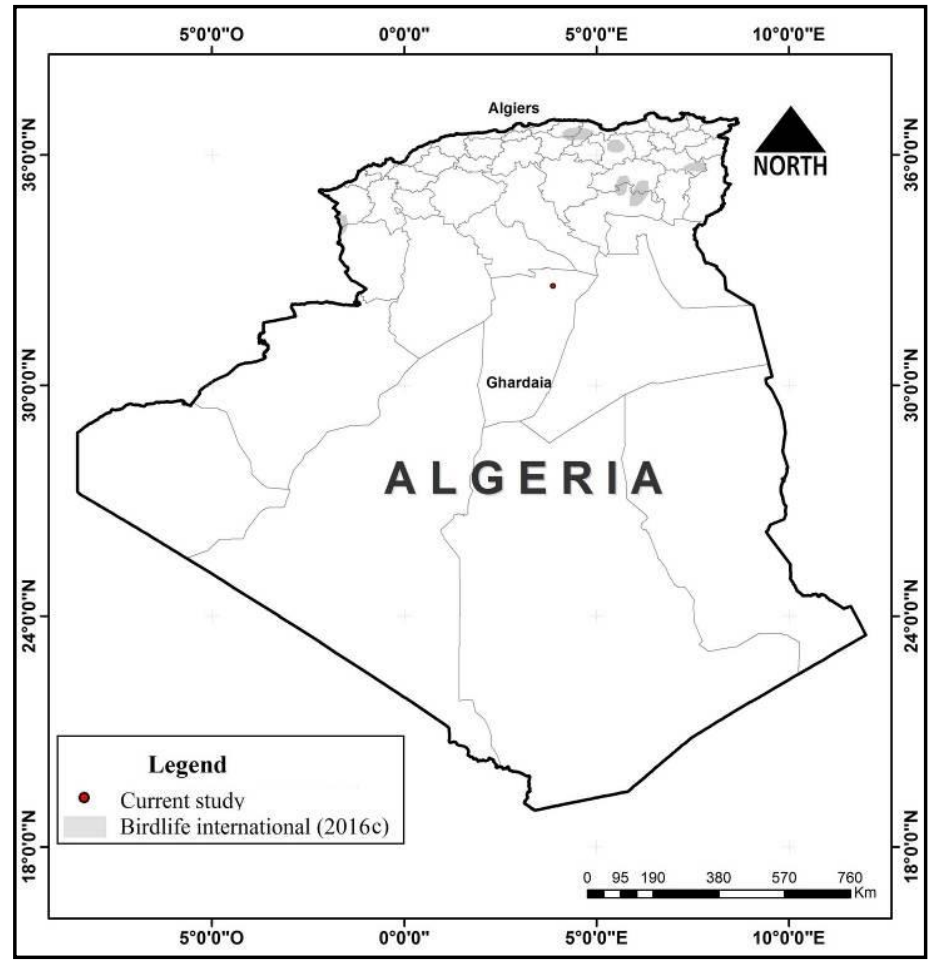

Figure 8. Maps showing previous and updated distributions of the Black-throated Wheatear (Oenanthe seebohmi) in Algeria

Eight Wheatear species reported in Ghardaïa out of 09 nationally were reported species (Algeria). These results show the importance of this region at the national level, where Ghardaïa considers a nesting and resident site, as well as a must-see site for migration in both directions, prenuptial in spring and postnuptial passage in autumn, where Ghardaïa region has already been confirmed for several waterbird species (Chedad et al. 2020c). At the international level, all species identified are of minor Concern according to the IUCN red list. At the international level, all species identified have a status of Least Concern in the IUCN Red List.

\section{CONCLUSIONS}

In The Algerian Sahara, especially the region of Ghardaïa, which contains an important avifaunistic diversity, sometimes a particular diversity, this fauna exploits this region as an essential stopover site, as well as resident and nest sites. The data collected so far on the wheatears are considered recent and preliminary and this could open the way for further research on the territory of Ghardaiia and its surroundings, in order to update the list of avifauna, to map the range, and set the phenological status of each species. Also, the continuation of the tracking of wheatears in this region given the recent climate 
Current Trends in Natural Sciences (on-line)

changes which certainly contribute to a change in the phenological status of wheatears species and on their reproduction.

\section{ACKNOWLEDGEMENTS}

First, we would like to thank the authorities of the General Directorate of Forests (Forest conservation, Ghardaïa) for facilitating our work on the ground. We also thank the members of the National Network of Algerian Ornithologist Observes "R.N.O.O.A." especially Ms. Oulmane K., Guechi R., Mezzi M., Horo A., Bendoui L., Ben Abderrahmane A. Ben Ahmed Z., Bendjedidi O., and Hadj Mhammed T. for their support and accompaniment during the study. We would like to thank Mr. Eisa A. for reading the paper before its submission, and our ornithologist Mr. Geuchi R. for the identification of certain species of birds.

\section{REFERENCES}

Ababsa, L., Sekour, M., Souttou, K., Guezoul, O. \& Doumandji, S. (2013). Quelques aspects sur l'avifaune dans deux palmeraies du Sahara septentrional (Algérie) [Some aspects about avifauna in two palm groves in the Northern Sahara (Algeria)]. Algerian journal of arid environment. 3(1), 59-67.

Arnault, C., (1931). Les traquets du Sud-Algérien [The Wheatears of the South-Algerian]. La Terre et la vie, 526-538.

Bendjoudi, D., Chenchouni, H., Doumandji, S. \& Voisin, J.F. (2013). Bird species diversity of the Mitidja Plain (Northern Algeria) with emphasis on the dynamics of invasive and expanding species. Acrocephalus, 34 (156-157), 13-26. https://doi.org/10.2478/acro-2013-0002

BirdLife International. (2016a). Oenanthe leucopyga. The IUCN Red List of Threatened Species 2016: e.T22710238A94240236. https://dx.doi.org/10.2305/IUCN.UK.2016-3.RLTS.T22710238A94240236.en. Downloaded on 15 March 2021.

BirdLife International. (2016b). Oenanthe deserti. The IUCN Red List of Threatened Species 2016: e.T22710325A89516443. https://dx.doi.org/10.2305/IUCN.UK.2016-3.RLTS.T22710325A89516443.en. Downloaded on 15 March 2021.

BirdLife International. (2016c). Oenanthe seebohmi. The IUCN Red List of Threatened Species 2016: e.T103773966A104220422. https://dx.doi.org/10.2305/IUCN.UK.2016-3.RLTS.T103773966A104220422.en. Downloaded on 14 April 2021.

BirdLife International. (2018). Oenanthe moesta. The IUCN Red List of Threatened Species 2018: e.T22710299A132086542. https://dx.doi.org/10.2305/IUCN.UK.2018-2.RLTS.T22710299A132086542.en. Downloaded on 15 March 2021.

BirdLife International. (2019a). Oenanthe lugens (amended version of 2018 assessment). The IUCN Red List of Threatened Species 2019: $\quad$ e.T106000073A155609396. https://dx.doi.org/10.2305/IUCN.UK.20182.RLTS.T106000073A155609396.en. Downloaded on 15 March 2021.

BirdLife International. (2019b). Oenanthe hispanica (amended version of 2016 assessment). The IUCN Red List of Threatened Species 2019: e.T22710302A155608614. https://dx.doi.org/10.2305/IUCN.UK.20193.RLTS.T22710302A155608614.en. Downloaded on 14 April 2021.

Blondel, J. (1975). L'analyse des peuplements d'oiseaux - éléments d'un diagnostic écologique. La méthode des échantillonnages fréquentiels progressifs (E.F.P) [Analysis of bird stands-elements of an ecological diagnosis. The method of progressive frequency sampling (E. F. P)]. Rev. Ecol. (Terre et Vie), 29(4), 533-589.

Chedad, A., Guezoul, O., Bendjoudi, D., Souffi, I., Horo, A. \& Tir I. (2018). Commensalisme entre la Tarente de mauritanie Tarentola mauritanica et le Traquet à tête blanche Oenanthe leucopyga leucopyga en Algérie /Commensalism between common wall gecko Tarentola mauritanica and White-crowned wheantear Oenanthe leucopyga leucopyga in Algeria. Alauda, 86 (4), 315 - 317.

Chedad, A., Guezoul, O. \& Bendjoudi, D. (2019). Un cas de leucisme chez le Traquet à tête blanche Oenanthe leucopyga en Algérie/A case of leucism en the White-crowned wheantear Oenanthe leucopyga in Algeria. Alauda, 87(4), 348.

Chedad, A., Bendjoudi, D. \& Guezoul, O. (2020a). Expansion of some species of the Fringillidae family in the Algerian Northern Sahara. Current Trends in Natural Sciences, 9 (18), 92 - 99.

Chedad, A., Bendjoudi, D. \& Guezoul, O. (2020b). New data on the wintering and sedentary life of the European turtle dove Streptopelia turtur in the Algerian Northern Sahara. Current Trends in Natural Sciences, 9 (17), 65-73. https://doi.org/10.47068/ctns.2020.v9i17.007 


\section{Current Trends in Natural Sciences}

Vol. 10, Issue 19, pp. 25-35, 2021

https://doi.org/10.47068/ctns.2021.v10i19.003

Current Trends in Natural Sciences (on-line)

ISSN: 2284-953X

Current Trends in Natural Sciences (CD-Rom)

ISSN-L: 2284-9521

ISSN: 2284-9521

ISSN-L: 2284-9521

Chedad, A., Bendjoudi, D. \& Guezoul, O. (2020c). Biodiversité de l'avifaune aquatique d'une zone humide artificielle à Kef Doukhane (Ghardaïa, Sahara Algérien) [Biodiversity of waterbirds in the artificial wetland of Kef Doukhane (Ghardaïa, Algerian Sahara)]. Bull. Soc. zool. Fr., 145(4), 383-400.

Chedad, A., Bendjoudi, D., Beladis, B., Guezoul, O., \& Chenchouni, H. (2021). A comprehensive monograph on the ecology and distribution of the House bunting (Emberiza sahari) in Algeria. Frontiers of Biogeography. 13.1, e47727, 1 - 19. http://dx.doi.org/10.21425/F5FBG47727 Retrieved from https://escholarship.org/uc/item/5hs9q97m.

Doumandji, S., Doumandji-Mitiche, B. (1994).Ornithologie appliquée à l'agronomie et à la sylviculture [Ornithology applied to agronomy and forestry] (pp.124). Ed. Off. Pub. Univ. Alger.

Farhi, Y. (2014). Structure et dynamique de l'avifaune des milieux steppique et présahariens et phoencicoles des Ziban [Structure and dynamics of the avifauna of steppe environments and pre-Saharan and phoenicicoles of the Ziban], Thèse de doctorat, Université Mohamed Khider, Biskra, 354 p.

Farhi, Y. \& Belhamra, M. (2012). Typologie et structure de l'avifaune des Ziban (Biskra, Algérie) [Typology and structure of the avifauna of the Ziban (Biskra, Algeria)]. Courrier du Savoir, (13), 127-136.

Fonderflick, J. (2006). -Suivi de la faune : méthodes de dénombrement des oiseaux [Wildlife monitoring : methods of counting birds]. Aten, 83, 1-7.

GBIF.org (15 mars 2021a) Occurrence Download GBIF https://doi.org/10.15468/dl.avt4uu.

GBIF.org (15 mars 2021b) Occurrence Download GBIF https://doi.org/10.15468/dl.jzfzr3.

GBIF.org (15 March 2021c) GBIF Occurrence Download https://doi.org/10.15468/d1.4avpdm.

GBIF.org (15 mars 2021d) Occurrence Download GBIF https://doi.org/10.15468/dl.wmw9xe.

GBIF.org (15 mars 2021e) Occurrence Download GBIF https://doi.org/10.15468/dl.jb3m65.

GBIF.org (15 April 2021f) GBIF Occurrence Download https://doi.org/10.15468/dl.cbpt5e.

GBIF.org (15 April 2021g) GBIF Occurrence Download https://doi.org/10.15468/dl.jyayz7.

Guezoul, O., Chenchouni, H., Sekour, M., Ababsa, L., Souttou, K. \& Doumandji, S.E. (2012). An avifaunal survey of mesic manmade ecosystems "Oases" in Algerian hot-hyperarid lands. Saudi Journal of Biological Sciences, 20(1): 37-43. https://doi.org/10.1016/j.sjbs.2012.10.001

Guezoul, O., Ababsa, L., Souttou, K. \& Sekour, M. (2017). Répartition des oiseaux dans quelques oasis de la partie septentrionale du Sahara) [Distribution of birds in some oases in the northern part of the Sahara)]. Courrier du Savoir, 23, 129-136.

Heim de Balsac, H. and Mayaud, N. (1962). Contribution à l'Ornithologie du Sahara Central et du Sud Algérien [Contribution to the Ornithology of the central Sahara and southern Algeria], Ed., Imprimerie. Le Typo-litho, Alger, 127.

Isenmann, P., Moali, A. (2000). Oiseaux d'Algérie [Birds of Algeria]. (pp.336) Société d'Etudes Ornithologiques de France, SEOF, Paris.

Mediouni, K. (1997). Organisation et potentialités de la diversité biologique Algérienne [Organization and potential of Algerian biological diversity]. (Tom II, pp.158) Min. Envi.,Projet Alg. /97 /G31/FEM/PNUD.

Moali, A. (1999). -Déterminisme écologique de la répartition des oiseaux le long d'un transect altitudinal en Kabylie (Algérie) [Ecological determinism of bird distribution along an altitudinal transect in Kabylia (Algeria)]. Thèse Doctorat d'état, Uni. M. Mammeri, Tizi Ouzou, 220 p.

Ochando, B. (1988). Méthode d'inventaire et de dénombrement d'oiseaux en milieux forestiers. Application à l'Algérie. [Inventory method and counting of birds in forest environments. Application to Algeria] Ann. Inst. Nati.Agro.,El Harrache, 12 (spécial), 47-59.

Samraoui, B. \& Bélair, G. (1998).- Les zones humides de la Numidie orientale : bilan des connaissances et perspectives de gestion [The wetlands of Eastern Numidia: knowledge balance and management prospects]. Synthèse (numéro spécial) 4, 1-90.

Shirihai, H. \& Svensson, L. (2018). -Handbook of Western Palearctic Birds: Passerines: Larks to Warblers. Vol. I. London, HELM Bloomsbury Publishing.

Souttou, K., Ababsa, L., Abidi, F., Guezoul, O., Sekour, M. \& Doumandji, S. (2018). Composition et Structure Avifaunistique dans une Steppe Arborée de Pin d'Alep à Chêne Vert à Sehary Guebli (Djelfa, Algerie) [Bird Composition and Structure in a Wooded Steppe from Aleppo Pine and Evergreen oak in Sehary Guebli (Djelfa, Algeria) ]. Lebanese Science Journal, 19 (1), 19-30.

Stevenson, A.C., Skinner, J., Hollis, G.E. \& Smart, M. (1988). - The El Kala national park and environs, Algeria. An ecological evaluation. Environ. Conservation, 15, 335-348.

UICN, (2020). The International Union for Conservation of Nature, IUCN Red list of Threatened Species, http://www.redlist.org/.

http://www.natsci.upit.ro

*Corresponding author, E-mail address: agrochedad@yahoo.fr 